\title{
Nutritional potassium requirement for laying Japanese quails
}

\author{
Fernando Guilherme Perazzo Costa $^{1}$, Ladyanne Raia Rodrigues ${ }^{2}$, Cláudia de Castro Goulart ${ }^{3}$, \\ Cleber Franklin Santos de Oliveira ${ }^{4}$, Valéria Pereira Rodrigues ${ }^{4}$, José Humberto Vilar da Silva ${ }^{5}$
}

\footnotetext{
1 Universidade Federal da Paraíba - UFPB, Centro de Ciências Agrárias - CCA/Departamento de Zootecnia, Areia-PB.

2 Curso de Graduação em Zootecnia, UFPB/CCA, Areia-PB.

3 Programa de Doutorado Integrado em Zootecnia, UFPB/CCA, Areia-PB. Universidade Estadual Vale do Acaraú - UVA, Centro de Ciências Agrárias e Biológicas - CCAB, Curso de Zootecnia, Sobral-CE.

4 Programa de Pós-Graduação em Zootecnia, UFPB/CCA, Areia-PB.

${ }^{5}$ Universidade Federal da Paraíba - UFPB, Centro de Ciências Humanas, Sociais e Agrárias - CCHSA/Departamento de Agropecuária, Bananeiras $-P B$.
}

\begin{abstract}
The objective of this study was to evaluate the potassium requirement for laying Japanese quails. Two hundred and forty quails were distributed in a randomized block design, with five treatments and six replicates, with eight birds each. The treatments consisted of a basal diet deficient in potassium $(\mathrm{K})(2.50 \mathrm{~g} / \mathrm{kg})$, supplemented with potassium carbonate, to replace the inert, to reach levels of $2.50,3.50,4.50,5.50$ and $6.50(\mathrm{~g} / \mathrm{kg})$ of $\mathrm{K}$ in the diet. There was a quadratic effect of $\mathrm{K}$ levels on feed intake, egg production, egg mass and feed conversion per egg mass and per egg dozen, estimating the requirements of 4.26, 4.41, 4.38, 4.43 and $4.48(\mathrm{~g} / \mathrm{kg})$ of $\mathrm{K}$ diet, respectively. There was no significant effect on the levels of $\mathrm{K}$ in the diet on egg weight, albumen weight, percentage of yolk or shell and yolk color. However, yolk and shell weights reduced and the albumen percentage increased linearly with increasing levels of $\mathrm{K}$ in the diet. Despite the reduction of shell weight, the increased levels of $\mathrm{K}$ did not influence the specific gravity and shell thickness. The use of $4.41 \mathrm{~g} / \mathrm{kg}$ of potassium is recommended in the diet for laying Japanese quails.
\end{abstract}

Key Words: egg production, electrolyte balance, mineral

\section{Introduction}

For many years, quail breeding was considered an alternative activity for small farmers. However, due to the potential of these birds for egg and meat production and the possibility of diversifying into marketing these products, the commercial quail exploration has grown in recent years, and is currently growing. For requiring smaller investment and labor force than other activities, combined with the excellent qualities of poultry production, this activity has attracted great interest from producers, companies and researchers (Murakami \& Garcia, 2006).

Due to the advances of genetics in this species, researches have been conducted in order to establish and constantly update the appropriate levels of nutrients in the diet, aiming at constant improvement in production rates of birds.

Until recently, there was great interest in determining the nutritional K requirements, since the diets for birds were made with high crude protein levels, and diets had large amounts of soybean meal (an ingredient rich in $\mathrm{K}$ ) and these formulations often provide excess of this mineral. However, with the advent of synthetic amino acids and the reality of reduced protein levels of diets, it is necessary to revise the minimum K requirements to ensure good performance and egg quality of birds.

According to Reece et al. (2000), high growth rate animals have relatively high $\mathrm{K}$ requirements, in the same way, increasing the protein content of the diet also increases the requirements for this mineral. The heat stress increases the excretion of $\mathrm{K}$ in urine and may result in reduced plasma K levels (Naseem et al., 2005). In avian species, K deficiency causes muscle weakness, problems in intestinal tonus, heart and respiratory muscles weakness (Reece et al., 2000).

Thus, the objective of this study was to estimate the potassium requirement for laying Japanese quails.

\section{Material and Methods}

The experiment was conducted at the poultry production module of the Centro de Ciências Agrárias, Departamento de Zootecnia, Universidade Federal da Paraíba. The experimental period lasted 84 days, divided into four periods of 21 days. Two-hundred and forty Japanese quails with 43 weeks of age were distributed in 
randomized block design with five treatments and six replicates of eight birds per experimental unit.

In the 15 days preceding the experiment, the egg production was recorded and the egg laying rate in the period was calculated for standardization of plots. The egg production and weight of quails means at the beginning of the experiment were $66.3 \pm 3.4 \%$ and $191.1 \pm 7.3 \mathrm{~g}$, respectively.

The treatments were a basal diet deficient in potassium $(2,50 \mathrm{~g} / \mathrm{kg})$ formulated to meet the requirements of laying quails according to the NRC (1994), and supplemented with potassium carbonate $\left(\mathrm{K}_{2} \mathrm{CO}_{3}-565 \mathrm{~g} / \mathrm{kg}\right.$ of $\left.\mathrm{K}\right)$, replacing the inert to achieve levels of 2.50, 3.50, 4.50, 5.50 and $6.50 \mathrm{~kg} / \mathrm{kg}$ of K (Table 1). The corn starch and corn gluten meal were used partially, replacing corn and soybean meal in order to cause $\mathrm{K}$ deficiency in the basal diet.

The electrolyte balance of the experimental diets was calculated using the Mogin formula (1981): $\mathrm{MN}=\mathrm{mEq} \mathrm{Na}{ }^{+}$ $+\mathrm{mEq} \mathrm{K}{ }^{+}-\mathrm{mEq} \mathrm{Cl}{ }^{-}$, and the milliequivalent $(\mathrm{mEq})$ was

Table 1 - Composition of basal diet

\begin{tabular}{|c|c|}
\hline Ingredient & (g/kg) \\
\hline Corn & 402.33 \\
\hline Starch & 256.46 \\
\hline Corn gluten meal & 145.52 \\
\hline Limestone & 53.21 \\
\hline Meat and bone meal & 42.17 \\
\hline Soybean meal & 40.78 \\
\hline Soybean oil & 30.00 \\
\hline L-lysine.HCl & 09.45 \\
\hline Salt & 04.82 \\
\hline DL-methionine & 2.28 \\
\hline L-tryptophan & 1.10 \\
\hline Choline chloride $60 \%$ & 1.00 \\
\hline Mineral premix ${ }^{1}$ & 1.00 \\
\hline Vitamin premix ${ }^{2}$ & 1.00 \\
\hline L-threonine & 0.78 \\
\hline Antioxidant ${ }^{3}$ & 0.10 \\
\hline Inert ${ }^{4}$ & 8.00 \\
\hline Total & 1000.00 \\
\hline \multicolumn{2}{|l|}{ Calculated composition } \\
\hline Metabolizable energy (kcal/kg) & 2.800 \\
\hline Crude protein $(\mathrm{g} / \mathrm{kg})$ & 171.2 \\
\hline Lysine digestible $(\mathrm{g} / \mathrm{kg})$ & 11.00 \\
\hline Methionine+cystine digestible $(\mathrm{g} / \mathrm{kg})$ & 7.90 \\
\hline Methionine digestible $(\mathrm{g} / \mathrm{kg})$ & 5.30 \\
\hline Threonine digestible (g/kg) & 5.90 \\
\hline Tryptophan digestible (g/kg) & 2.00 \\
\hline Sodium $(\mathrm{g} / \mathrm{kg})$ & 2.30 \\
\hline Chlorine (g/kg) & 3.41 \\
\hline Potassium $(\mathrm{g} / \mathrm{kg})$ & 2.50 \\
\hline Electrolyte balance (mEq/kg) & 67.802 \\
\hline \multicolumn{2}{|c|}{$\begin{array}{l}{ }^{1} \text { Unimix Sais Minerais (composition per kg): Mn: 75,000 mg; Zn: 70,000 mg; Fe: } \\
\text { 50,000 mg; Cu: 8,500 mg; I: 1,500 mg; Co: } 200 \mathrm{mg} \text { and Vehicle: } 1,000 \mathrm{~g} \\
2 \text { Unimix Codorna (composition per kg): Vit A: 7,000,000 UI; Vit D3: 2,100,000 UI; } \\
\text { Vit E: 50,000 mg; Vit K3: 2,000 mg; Vit B1: 2,000 mg, Vit B2: 4,000 mg; Vit B6: } \\
\text { 3,000 mg; Vit B12: 3,000 mg; Nicotinic acid: } 39,800 \mathrm{mg} \text {; Pantothenic acid: } \\
\text { 15,620 mg; Folic acid: } 1,000 \mathrm{mg} \text { : Selenium: } 200 \mathrm{mg} \text {; Biotin: } 100 \mathrm{mg} \text {; } \\
\text { Antioxidant: } 100,000 \mathrm{mg} \text { and Vehicle: } 1,000 \mathrm{~g} \text {. } \\
3 \text { Etoxiquim: } 10 \text { g, and vehicle q.s.p.: 1,000 g. } \\
{ }^{4} \text { Sand. }\end{array}$} \\
\hline
\end{tabular}

calculated as: $\mathrm{mEq}=\%$ of electrolyte diet $\mathrm{x}$ 10000/atomic mass of the electrolyte. The electrolyte balance of diets with 2.50, 3.50, 4.50, 5.50 and $6.50 \mathrm{~kg} / \mathrm{kg}$ of K were 68, 93, 119, 145 and $170 \mathrm{mEq} / \mathrm{kg}$ and the $(\mathrm{Na}+\mathrm{K}) / \mathrm{Cl}$ relations were $1.4,1.7$, 2.0, 2.3 and 2.6, respectively.

Quails were housed in galvanized cages with dimensions of $33 \times 33 \times 14 \mathrm{~cm}$ and received water and food ad libitum. The light program used was continuous light for 24 hours per day (natural + artificial).

At the end of each period, the following variables were evaluated: feed intake (FI, g/bird/day), egg production (EP, \%/bird/day), egg weight (EW, g), egg mass (EM, g/bird/day), feed conversion (FCM, kg/kg) per mass and per dozen (FCD, kg/dozen) of eggs, weight of albumen (WA, g), yolk (WY, g) and shell (WS, g), percentages of albumen (A, \%), yolk (Y, \%) and shell (S, \%) and specific gravity (SG, g/ $\mathrm{cm}^{3}$ ) of eggs.

At the end of each experimental period, the leftovers from the diets of each plot were collected for feed intake calculation. The egg collection was performed twice daily (9 a.m. and 3 p.m.), recording the laying frequency, number of defective and intact eggs and mortality rate. Egg production in percentage was calculated by dividing the total number of eggs per plot by the number of birds by the number of days. The eggs from the last three days of each experimental period were individually weighed to obtain the average weight. The egg mass calculation was performed by multiplying egg production by average egg weight per plot. The feed conversion by egg mass was calculated by the relationship between feed intake and egg mass produced. The conversion per dozen eggs was calculated as the ratio between intake and production, and the result was divided by 12 .

From the total eggs produced per replicate, six units were selected randomly to determine weight and percentages of yolk, albumen and shell. After manual separation of these components, shells were kept in forced ventilation oven at $65^{\circ} \mathrm{C}$ for 4 hours. The relative weight of the yolk, albumen and shell were obtained by dividing the weight of each component by weight of the egg, multiplying the result by 100 .

The specific gravity was determined by saline flotation technique, according to methodology described by Hamiltom (1982). At the end of each experimental period, two eggs per plot were selected in order to avoid broken or defective eggs. Then, the immersion of eggs in salt solutions with densities from 1.060 to 1.100 was performed, with interval of 0.0025. Eggs were placed in buckets with the solutions from lowest to highest density and taken out when floating, recording the values of densities 
corresponding to the solutions of each containers. Before each evaluation, the densities were checked with petroleum densimeter.

The data were analyzed by the System for Statistics and Genetics Analysis (SAEG), developed at the Universidade Federal de Viçosa (1999). Regression analysis was performed using linear and quadratic effects $5 \%$ probability to determine the potassium requirements.

\section{Results and Discussion}

Quadratic effect of potassium levels was observed $(\mathrm{P}<0.05)$ on broiler performance corroborating Junqueira (2004), who claims that inadequate amounts of potassium can affect performance, which was observed in this experiment (Table 2).

Quadratic effect $(\mathrm{P}<0.01)$ of $\mathrm{K}$ levels was observed on feed intake, egg production, egg mass, conversion per egg mass and per dozen eggs, estimating requirements of 4.26 , $4.41 ; 4.38,4.43$ and $4.48 \mathrm{~kg} / \mathrm{kg}$ of $\mathrm{K}$ in the diet, corresponding to electrolyte balance of 113, 117, 116, 117 and $118 \mathrm{mEq} / \mathrm{kg}$, respectively. The K requirements in the diet were determined according to equations in Table 3.

Feed intake was quadratically affected by $\mathrm{K}$ levels in the diet, responding positively to the increase of $\mathrm{K}$ up to the value of $0.426 \%$ according to equation (Table 3 ), from this level, the feed intake decreased, being the lowest in the highest $\mathrm{K}$ levels.

In this system, when sodium is pumped against its concentration gradient, $\mathrm{K}$, amino acids and glucose enter the cell by both active transport and passive diffusion
(Nelson \& Cox, 2000). Despite its different transport system, $\mathrm{K}$, amino acids and glucose depend on the sodium concentration to be transported. Thus, since the sodium content remains the same in the diets, with increasing levels of $\mathrm{K}$, the exceeding $\mathrm{K}$ is competing for sodium with the amino acids in transport systems, resulting in a higher concentration of amino acids in the bloodstream, which may lead to inhibition of the hunger center in the hypothalamus and, consequently, reduce the food intake.

Another problem cited by Granner (1998) is that when there is excess of $\mathrm{K}$, the body fails to eliminate $\mathrm{H}^{+}$protons and starts to eliminate $\mathrm{K}^{+}$, interfering with the electrolyte balance and, consequently, with the acid-base balance. The electrolyte balance refers to the ionic balance of body fluids to regulate the acid-base balance in order to maintain the organic homeostasis (Vieites et al., 2004). In other words, the electrolyte balance is the difference between the major cations and anions in the diet and represents its metabolic acidogenicity or alkalinity. According to Macari et al. (2004), the maintenance of the acid-base balance is of fundamental importance in physiological and biochemical processes involved in the animal body, considering that the cellular enzymes, the electrolyte exchanges and the maintenance of the structural status of proteins are directly affected by small variations in blood $\mathrm{pH}$. Potassium supplementation (high $\mathrm{mEq}$ ) increases the $\mathrm{pH}$ (alkalosis), because this element has alkalinizing effect. Therefore, the inhibition in consumption could then be a physiological response to increased blood $\mathrm{pH}$.

Egg production responded to the increased $\mathrm{K}$ levels of diet similarly to feed intake, increasing to the level of $4.41 \mathrm{~g} / \mathrm{kg}$

Table 2 - Feed intake (FI), egg production (EP), egg weight (EW), egg mass (EM), feed conversion per egg mass (FCM) and egg dozen (FCD) of Japanese quails, according to potassium levels of the diet

\begin{tabular}{|c|c|c|c|c|c|c|}
\hline Potassium (\%) & FI (g/bird/day) & EP (\%/ave/dia) & EW (g) & EM (g/bird/day) & FCM $(\mathrm{kg} / \mathrm{kg})$ & FCD (kg/dozen) \\
\hline 0.25 & 18.28 & 42.63 & 9.68 & 4.13 & 4.430 & 0.515 \\
\hline 0.35 & 19.29 & 46.56 & 10.10 & 4.70 & 4.102 & 0.497 \\
\hline 0.45 & 19.16 & 51.40 & 9.83 & 5.05 & 3.792 & 0.447 \\
\hline 0.55 & 18.77 & 46.72 & 9.58 & 4.48 & 4.194 & 0.482 \\
\hline 0.65 & 17.78 & 40.67 & 9.82 & 3.99 & 4.452 & 0.525 \\
\hline Mean & 18.66 & 45.60 & 9.80 & 4.47 & 4.194 & 0.493 \\
\hline Regression & $\mathrm{Q} * *$ & $\mathrm{Q} * *$ & NS & $\mathrm{Q} * *$ & $\mathrm{Q} * *$ & $\mathrm{Q} * *$ \\
\hline CV (\%) & 3.85 & 1.79 & 3.71 & 3.35 & 4.62 & 3.47 \\
\hline
\end{tabular}

$\mathrm{Q}^{* *}=$ quadratic effect at $1 \%$ probability; $\mathrm{CV}=$ coefficient of variation.

Table 3 - Equations estimated for the productive parameters of Japanese quails

\begin{tabular}{llc}
\hline Production function & \multicolumn{1}{c}{ Equation } & Set point \\
\hline Feed intake & $\mathrm{y}=13.76+26.073 \mathrm{x}-30.597 \mathrm{x}^{2}$ & 0.426 \\
Egg production & $\mathrm{y}=8.5478+187.13 \mathrm{x}-211.95 \mathrm{x}^{2}$ & 0.441 \\
Egg mass & $\mathrm{y}=0.6945+19.256 \mathrm{x}-21.97 \mathrm{x}^{2}$ & 0.438 \\
Feed conversion per egg mass & $\mathrm{y}=6.63-12.194 \mathrm{x}+13.756 \mathrm{x}^{2}$ & 0.443 \\
Feed conversion per egg dozen & $\mathrm{y}=0.7606-1.3209 \mathrm{x}+1.4732 \mathrm{x}^{2}$ & 0.92 \\
\hline
\end{tabular}


of $\mathrm{K}$ in the diet, decreasing at higher levels. The quadratic response could be observed also for variables egg mass, conversion per egg mass and per dozen eggs, in which the response of birds was improved with increasing levels of $\mathrm{K}$ up to $4.38,4.43$ and $4.48 \mathrm{~g} / \mathrm{kg}$ respectively, and worsened with $\mathrm{K}$ levels above these values, showing that both deficiency and excess of K can be detrimental to the productive performance of birds.

The electrolyte balance corresponding to K levels that optimized the productive performance were in the range from 113 to $118 \mathrm{mEq} / \mathrm{kg}$ in a range of study from 68 to $170 \mathrm{mEq} / \mathrm{kg}$. Few studies have been conducted to determine the electrolyte balance of diets for Japanese quails. Lobato et al. (2009), working with diets with different combinations of sodium (2.30 or $1.50 \mathrm{~g} / \mathrm{kg}$ ), chlorine $(2.30$ or $1.50 \mathrm{~g} / \mathrm{kg})$ and potassium (4.60 or $7.60 \mathrm{~g} / \mathrm{kg}$ ) contents, found that birds fed with diets containing higher $\mathrm{K}$ levels showed better performance. Moreover, in diets low in $\mathrm{K}$, increasing the $\mathrm{Na}$ level promoted improvement in egg production and feed conversion of quails. These authors recommended electrolyte balance above $153 \mathrm{mEq} / \mathrm{kg}$ for best performance of Japanese quails.

For laying quails, Cohen \& Hurwitz (1974) suggest that the $(\mathrm{Na}+\mathrm{K}) / \mathrm{Cl}$ ratio be above 1.5 to prevent the decrease in blood $\mathrm{pH}$ during the eggshell formation. However, Hamilton and Thompson (1980) found negative effects of $(\mathrm{Na}+\mathrm{K}) / \mathrm{Cl}$ ratios below 1.91 or above 2.83 on feed efficiency, egg production and eggshell weight. In this study, the $(\mathrm{Na}+\mathrm{K}) / \mathrm{Cl}$ ratio that resulted in the best performance was 171.

According to Vieites et al. (2005), the electrolytes of the diet consumed by animals influenced the acid-base balance and consequently affected the metabolic processes, disease resistance, survival to stress and performance parameters. Possibly, the acid-base balance considerably affected the productive response of birds whose diets were supplemented with high potassium carbonate levels.

Changes in the acid-base balance and imbalances in the $\mathrm{Na}, \mathrm{K}$ and $\mathrm{Cl}$ supplementation cause loss of appetite, reduction in weight gain, affecting feed conversion, and causing drop in egg production (Borges, 2003b). It appears that the interrelationship between electrolytes affects the performance of birds both when providing levels of minerals that are outside the nutritional requirement and when changing the optimum relationship between them. According to Lobato et al. (2009), birds require minimal amounts of $\mathrm{K}$ in their diet to meet their physiological needs, and in addition, the ratio between $\mathrm{K}$, chlorine and sodium (electrolyte balance) should be maintained. Borges et al. (1999), working with broilers, found that at high electrolyte relations obtained by K supplementation in the diet, the growth of the birds was depressed.

According to Borges et al. (2003a), alkalosis causes a reduction in competition between $\mathrm{H}^{+}$and $\mathrm{K}^{+}$for urinary excretion and therefore increases the loss of $\mathrm{K}^{+}$in urine. Excess of $\mathrm{K}^{+}$competes with the buffer anions from the renal tubular fluid, preventing the removal of $\mathrm{H}^{+}$, which is reabsorbed and can lead to acidosis. In turn, the increase in $\mathrm{Cl}^{-}$suppresses the excretion of $\mathrm{H}^{+}$and $\mathrm{HCO}_{3}$ reabsorption by the kidneys, which can contribute for the blood acidification.

On the other hand, in the metabolic acidosis, the plasma concentration of bicarbonate and $\mathrm{pH}$ are below normal, with depletion of plasma cations such as $\mathrm{Na}^{+}$and $\mathrm{K}^{+}$, with consequent compromising of the $\mathrm{Na}^{+}$and $\mathrm{K}^{+}$ pump system, preventing the absorption of amino acids and glucose into the cells of birds. Rinehart et al. (1968) showed that birds fed with diets poor in $\mathrm{K}$ had a lower level of free amino acids in plasma, but, as the diet was supplemented with $\mathrm{K}$, the arginine and lysine levels in plasma increased.

The different $\mathrm{K}$ recommendations for the performance of Japanese quails found in the literature may be associated with the use of birds from different strains or ages, varying for environmental conditions and nutritional effects of other dietary components, since the combination of these factors can provide different responses to the parameters evaluated.

No significant effect $(\mathrm{P}>0.05)$ of dietary K levels on absolute weight of albumen, relative weights of yolk and eggshell, yolk color and specific gravity was observed. However, the absolute weights of yolk $(\mathrm{P}<0.01)$ and shell $(\mathrm{P}<0.05)$ reduced and the relative albumen weight $(\mathrm{P}<0.01)$ increased linearly with increasing $\mathrm{K}$ levels in the diet. Reduction of $0.008 \mathrm{~g}$ in the yolk weight ( $\hat{\mathrm{y}}=2.7588$ $\left.0.0838 \mathrm{x}, \mathrm{r}^{2}=0.66\right)$ and $0.001 \mathrm{~g}$ in the shell weight ( $\hat{y}=0.8722-0.0156 x, r^{2}=0.88$ ) could be estimated for each $0.1 \%$ increase in $\mathrm{K}$ content of the diet (Table 4 ).

According to Vincenzi (1996), the acid-base balance of serum and uterine fluid is changed during the calcification process. The formation of $\mathrm{CO}_{3}$ ion at the uterus level produces acidosis that is compensated by means of hyperventilation and acidification of the urine. If the birds receive a diet with high acidogenic potential, the compensation means may fail to maintain the $\mathrm{pH}$ and acidosis may occur, which has negative effect on shell quality due to the reduction of plasma bicarbonate. Calderon (1994) reports that the increased sodium and 
Table 4 - Albumen (AW), yolk (YW) and shell (SW) weights, albumen, yolk and shell percentages, yolk color (YC) and specific gravity (SG) of quail eggs, according to potassium levels in the diet

\begin{tabular}{|c|c|c|c|c|c|c|c|c|}
\hline Potassium (\%) & AW (g) & YW (g) & SW (g) & Albumen (\%) & Yolk (\%) & Shell (\%) & YC & $\mathrm{SG}\left(\mathrm{g} / \mathrm{cm}^{3}\right)$ \\
\hline 0.25 & 6.24 & 2.59 & 0.86 & 64.18 & 25.21 & 8.39 & 5.98 & 1.0677 \\
\hline 0.35 & 6.47 & 2.75 & 0.84 & 64.11 & 26.70 & 8.21 & 5.47 & 1.0681 \\
\hline 0.45 & 6.50 & 2.46 & 0.83 & 66.13 & 25.14 & 8.45 & 6.09 & 1.0684 \\
\hline 0.55 & 6.36 & 2.39 & 0.79 & 66.09 & 25.19 & 8.41 & 6.08 & 1.0671 \\
\hline 0.65 & 6.58 & 2.35 & 0.80 & 67.33 & 24.03 & 8.25 & 6.20 & 1.0672 \\
\hline Mean & 6.43 & 2.51 & 0.82 & 65.57 & 25.25 & 8.34 & 5.97 & 1.0677 \\
\hline Regression & NS & $\mathrm{L}^{*}$ & $\mathrm{~L}^{*}$ & $\mathrm{~L}^{*}$ & NS & NS & NS & NS \\
\hline CV (\%) & 5.77 & 6.87 & 5.22 & 3.01 & 6.87 & 4.87 & 8.23 & 0.16 \\
\hline
\end{tabular}

$\mathrm{L}=$ linear effect at $5 \%$ probability; NS = not significant; $\mathrm{CV}=$ coefficient of variation.

potassium levels in the diet would induce to alkalosis, which could overcome the acidosis, with increased quality of the eggshell. Similarly, Gonzales (1999) reports that shell quality is improved as the Na and K levels increase, but it worsens with excessive $\mathrm{Cl}$. However, in this study, reduction in the absolute weight of the shell with increasing K levels was observed. Nevertheless, despite the reduction in shell weight, the increased K levels did not influence the specific gravity or shell thickness, and it could be inferred that the external quality of quail eggs was not affected by the $\mathrm{K}$ levels studied.

Moreover, for each increase of $1.0 \mathrm{~g} / \mathrm{kg}$ of $\mathrm{K}$ in the diet, an increase of $0.82 \%$ in the relative albumen weight $\left(\hat{\mathrm{Y}}=61.87+8.2 \mathrm{x}, \mathrm{r}^{2}=0.88\right)$ is estimated. According to Gonzales (1999), birds are naturally predisposed to metabolic acidosis in the period of rapid growth of the bone tissue or during shell calcification (laying phase), by removing calcium and adding $\mathrm{H}^{+}$to the bloodstream. About $40 \%$ of the buffering of metabolic acidosis occurs in the bone, with release of $\mathrm{Na}^{+}$and $\mathrm{K}^{+}$in exchange for the excess of $\mathrm{H}^{+}$, which starts when there is a decrease in plasma concentration of bicarbonate ion $\left(\mathrm{HCO}_{3}\right)$, the main blood buffer. Therefore, it is expected that the supply of a diet balanced in electrolytes such as $\mathrm{K}^{+}$enhances the natural systems of physiological acidity buffering, resulting in better performance and egg quality. According to Miles \& Rossi (1984), the high concentration of anions in the diet decreases the eggshell quality and lowers the $\mathrm{pH}$, while high concentration of cations is associated with improvement in shell quality and higher blood $\mathrm{pH}$.

According to Souza (2002), the K concentration stimulates the release of the growth hormone, which inhibits the lipogenesis and increases the lipolysis, reducing the carrying of fat to the yolk; this may justify the decrease in weight, since much of its content is formed by lipids.

These results demonstrate that the $\mathrm{K}$ levels used in the diets for commercial quails may be lower than those recommended by NRC (1994).

\section{Conclusions}

The use of $4.41 \mathrm{~g} / \mathrm{kg}$ of potassium is recommended in the diet for laying Japanese quails.

\section{References}

BORGES, S.A.; SILVA, A.V.F.; ARIKI, J. et al. Dietary electrolyte balance for broiler chickens under moderately high ambient temperatures and relative humidities. Poultry Science, v.82, p.301-308, 2003a.

BORGES, S.A.; SILVA, A.V.F.; ARIKI, J. et al. Dietary electrolyte balance for broiler chickens exposed to thermoneutral or heatstress environments. Poultry Science, v.82, p.428-435, 2003b.

BORGES, S.A.; ARIKI, J.; SANTIN, E. et al. Balanço eletrolítico em dieta pré-inicial de frangos de corte durante o verão. Revista Brasileira de Ciência Avícola, v.1, n.3, p.175-179, 1999.

CALDERON, C. Efectos nutricionales sobre la calidad de la cáscara. In: CONFERÊNCIA APINCO 1994 DE CIÊNCIA E TECNOLOGIA AVÍCOlAS, Santos. Anais... Santos: FACTA, 1994. p.35-66.

COHEN, I.; HURWITZ, S. The response of blood ionic constituents and acid-base balance to dietary sodium, potassium and chloride in laying fowls. Poultry Science, v.53, p.378-382, 1974.

GONZÁLES, E.A qualidade da casca de ovo. Revista Alimentação Animal, n.16, 1999.

GRANNER, K.D. Hormônios da córtex da adrenal. In: HARPER, J.C. (Ed.) Bioquímica. 8.ed. São Paulo: Atheneu, 1998. p.707-709.

HAMILTOM, R.M.G. Methods and factors that affect the measurement off egg shell quality. Poultry Science, v.61, p.2002-2039, 1982.

HAMILTON, R.M.G.; THOMPSON, B.K. Effects of sodium plus potassium to chloride ratio in practical type diets on blood gas levels in three strins of White Leghorn hens and the relationship between acid-base balance and egg shell strength. Poultry Science, v.59, p.1294-1303, 1980.

JUNQUEIRA, O.M. [2004]. O potássio na nutrição dos animais. Serrana Nutrição Animal. Available on: <http://www.serrana.com.br/ nutricaoanimal/boletimtecnico integra.asp?id=61> Accessed on: Dec. 19, 2009.

LOBATO, G.B.V.; FIGUEIREDO-LIMA, D.F.; COSTA, F.G.P. et al. Efeito dos níveis de sódio, cloro, potássio e balanço eletrolítico no desempenho de codornas japonesas. In: ZOOTEC 2009, Águas de Lindóia. Anais... Águas de Lindóia: ZOOTEC 2009. (CD-ROM).

MACARI, M.; FURLAN, R.L.; GONZALEZ, E. Fisiologia aviária aplicada a frangos de corte. Jaboticabal: Universidade Estadual Paulista, 2004. 375p.

MILES, R.D.; ROSSI, A. Cation-anion balance in laying hens. In: FLORIDA NUTRITIONAL CONFERENCE, 1984, Clearwater Beach. Proceedings... Clearwater Beach: University of Florida, 1984. p.15-22. 
MONGIN, P. Recent advances in dietary anion-cation balance: applications in poultry. Proceedings Nutrition Society, v.40, p.285-294, 1981

MURAKAMI, A.E., GARCIA, E.R.M. Novas tecnologias no sistema de produção de codornas. In: CONGRESSO LATINOAMERICANO DE NUTRIÇÃO ANIMAL, 2., 2006, São Paulo. Anais... São Paulo: CBNA-AMENA, 2006. (Palestra Técnica).

NASEEM, M.T.; NASEEM, S.; YOUNUS, M. et al. Effect of potassium chloride and sodium bicarbonate supplementation on thermotolerance of broilers exposed to heat stress. International Journal of Poultry Science, v.4, n.11, p.891-895, 2005.

NATIONAL RESEARCH COUNCIL - NRC. Subcommittee on Poultry Nutrition. Committee on Animal Nutrition. Nutrient requirements of poultry. 9.ed. Washington, D.C.: National Academy Press, 1994. 155p.

NELSON, D.L.; COX, M.M. Lehninger: principles of biochemistry. 3.ed. New York: Worth Publishers, 2000. 1152p.

REECE, W.O.; SELL, J.L.; TRAMPEL, D.W. et al. Effects of dietary potassium supplementation for growing turkeys on leg weakness, plasma potassium concentration and selected blood variables. Poultry Science, v.79, p.1120-1126, 2000.

RINEHART, K.E.; FEATHERSTON, W.R.; ROGLER, J.C. Effects of a dietary potassium deficiency on protein synthesis in the young chick. Journal of Nutrition, v.95, n.4, p.627-632, 1968.

SOUZA, B.B.I.; BERTECHINI, A.G.; TEIXEIRA, A.S. et al. Efeitos dos cloretos de potássio e de amônia sobre o desempenho e deposição de gordura na carcaça de frangos de corte criados no verão. Revista Brasileira de Ciência Avícola, v.4, n.3, p.209-218, 2002.

UNIVERSIDADE FEDERAL DE VIÇOSA - UFV. SAEG. Sistema de análises estatísticas e genéticas. Versão 9.0. Viçosa MG: Fundação Arthur Bernardes, 1999. (CD-ROM).

VICENZI, E. Fadiga de gaiola e qualidade da casca do ovo. Aspectos nutricionais. In: SIMPÓSIO TÉCNICO DE PRODUÇÃO DE OVOS - APA, 6., 1996, São Paulo. Anais... São Paulo: APA, 1996. p.77-91.

VIEITES, F.M., MORAES, G.H.K., ALBINO, L.F.T. et al. Balanço eletrolítico e níveis de proteína bruta sobre o desempenho de pintos de corte de 1 a 21 dias de idade. Revista Brasileira de Zootecnia, v.33, n.6, p.2076-2085, 2004.

VIEITES, F.M., MORAES, G.H.K., ALBINO, L.F.T. et al. Balanço eletrolítico e níveis de proteína bruta sobre o desempenho, o rendimento de carcaça e a umidade da cama de frangos de corte de 1 a 42 dias de idade. Revista Brasileira de Zootecnia, v.34, n.6, p.1990-1999, 2005. 